Global Conferences Series:

Sciences and Technology (GCSST), Volume 3, 2020

The $1^{\text {st }}$ International Conference on Education, Sciences and Technology

DOI: https://doi.org/10.32698/tech3231

\title{
Student Satisfaction on Distance Education Academic Services
}

\author{
Rhini Fatmasari ${ }^{1,3}$ dan Zuwirna ${ }^{2}$ \\ ${ }^{1}$ Universitas Terbuka \\ ${ }^{2}$ Universitas Negeri Padang \\ "riens@ecampus.ut.ac.id
}

\begin{abstract}
Universitas Terbuka is the 45th State University in Indonesia that implements open and distance education. Educational services are delivered through modules and internet-based media. Developments at technological cause internet-based electronic media to be more used. In the 2018.1 semesters, the number of UT students was 302,484 people at 38 UT Regional Offices throughout Indonesia and 2,099 students at 39 Countries. Generally, academic services provided by UT to students include services at 1) guidance from study programs with distance education models; 2) registration services; 3) student learning materials (modules and non-print teaching materials); 4) face-to-face and online tutorials; 5) learning assistance counselling services; and 6) evaluation of learning. The level of student satisfaction with UT's academic services needs to be measured regularly to maintain service quality. This research was conducted on UT students with a sample of 370 students from 13 UT Regional Office. Sampling is representative of students from the regions of Western Indonesia, Central Indonesia, and Eastern Indonesia. Data is processed using Importance-Performance Analysis (IPA) and Customer Satisfaction Index (CSI). In general, the level of student satisfaction with distance education attributes is at the value of $90.20 \%$. That is, students feel very good satisfaction with the services provided by UT include aspects of distance education study programs and models, registration, teaching materials (modules and non-print teaching materials), face-to-face tutorials and online tutorials, learning assistance counselling services, and evaluation learn. When examined in more detail, there are several aspects that are above or below the index value $(90.20 \%)$, for example, the number of face-to-face Tutorial meetings 8 times in one semester and online Tutorials can be accessed easily. Analysis with CSI shows that $6,3 \%$ academic services are in quadrant $\mathrm{A}, 54,2 \%$ services are in quadrant $\mathrm{B}, 29,2 \%$ services are on quadrant $\mathrm{C}$ and $10,4 \%$ services on quadrant $\mathrm{D}$.
\end{abstract}

\section{Introduction}

Universitas Terbuka (UT) is the 45th University in Indonesia which implements open and distance learning systems. The term distance means learning is not done face-to-face, but uses media, both print (module) and non-print (audio / video, computer / internet, radio broadcasts, and television)[1]. While open means there are no restrictions on age, year of diploma, period of study, time of registration, and frequency of taking the exam.

Copyright ( 9 2019, the Authors. Published by Redwhite Press. 
As a university that implements a distance learning system, UT students are expected to learn independently. This way of learning requires students to study on their own initiative or initiative. Self-study can be done alone or in groups, both in study groups and in tutorial groups. UT provides teaching materials that are designed to be studied independently. In addition to using teaching materials provided by UT, students can also take the initiative to take advantage of other reading material in the library following the tutorial, both face-to-face and through the internet, radio and television; and utilizing other learning resources such as computer-assisted teaching materials and audio / video programs[2]. When experiencing learning difficulties, students can request information about study assistance to the UT Regional Office in 39 provinces in Indonesia. Currently UT is a teaching university that has an academic service reach to the outermost, disadvantaged, and poorest areas. Besides that UT also has to be able to reach Indonesian citizens who work abroad but still want to take higher education [3].

The focus of attention in the UT Strategic Plan focuses on student services as the core business. Student services are provided in the form of academic services and non-academic services. UT's academic services include services: a) registration, b) face-to-face tutorials and remote tutorials via radio, television, and the internet, and c) academic consultations. While non-academic services are given in the form of: a) information services, b) learning assistance, c) academic guidance; d) academic administration; d) customer complaints; and e) libraries. This service is intended to help students overcome academic and academic administration problems faced while studying at UT.

The academic and non-academic services provided by UT are described in the UT Strategic Plan of UT's strategic programs, namely: (1) improving the quality and academic services, (2) increasing the reach of education services and increasing public recognition of UT. The consequence of the UT Strategic Plan requires UT to provide higher education services to all levels of society so that accessibility becomes the main mandate. As a teaching university, UT needs to improve its quality in learning expected final product is UT's ability to provide academic services through world-class distance learning with a high level of accessibility with high-quality output. In the end, improving the quality of inputs, processes, and outputs will increase UT's academic authority. Now UT is paying full attention to the availability of adequate and integrated ICT facilities to support academic and nonacademic services [3].

\section{Customer Satisfaction}

Customer satisfaction is how customers view an organization's products or services in or the product, as well as comparison with what they have heard or seen about other companies or organizations. Customer satisfaction is one of the elements to be measured[4].Customer satisfaction is rooted in two ideas about quality. Quality can be measured by the gap between customer expectations and the service performance they receive. Product quality will be considered good if the services provided are in accordance with customer expectations. The ISO 9000 standard describing quality is about conformance to standards or specifications. After the design is set, the quality is good and ensures that the final results delivered to customers meet this design. Customer satisfaction is about monitoring the quality of product and service delivery[4].

In companies where customer satisfaction is a top priority, the customer survey process and the results are very high prominence throughout the organization. Customer satisfaction is based on meeting or exceeding customer requirements. To achieve this, the organization must do the best that is most important to the customer. The customer satisfaction measurement program will provide information that will enable organizations to: (1) accurately identify customer requirements and their relative importance; (2) understand how customers perceive the organization and whether the performance they receive has met their requirements; (3) identifying PFI (priority for improvement); (4) knowing the ability of service staff to meet customer needs; (5) setting goals for service improvement and monitoring progress towards customers satisfaction index; (3). Many methods used in measuring customer satisfaction. Bell (1995), used a survey method at Leicester University to measure student satisfaction with the services provided(5). 


\section{UT Academic Services}

As a service that supports academic services, UT also provides student services in the form of administrative services, which are focused on providing assistance to students in registration, obtaining teaching materials, transfer of credit, and other things that can affect student learning. Facilities owned by universities aim to improve organizational performance. In the context of higher education, facilities have two objectives, the first can be essential facilities in attracting and retaining key research students and potential students.

UT activities in educational services both those directly related to academic services and Academic support services can be illustrated in the following chart[3].

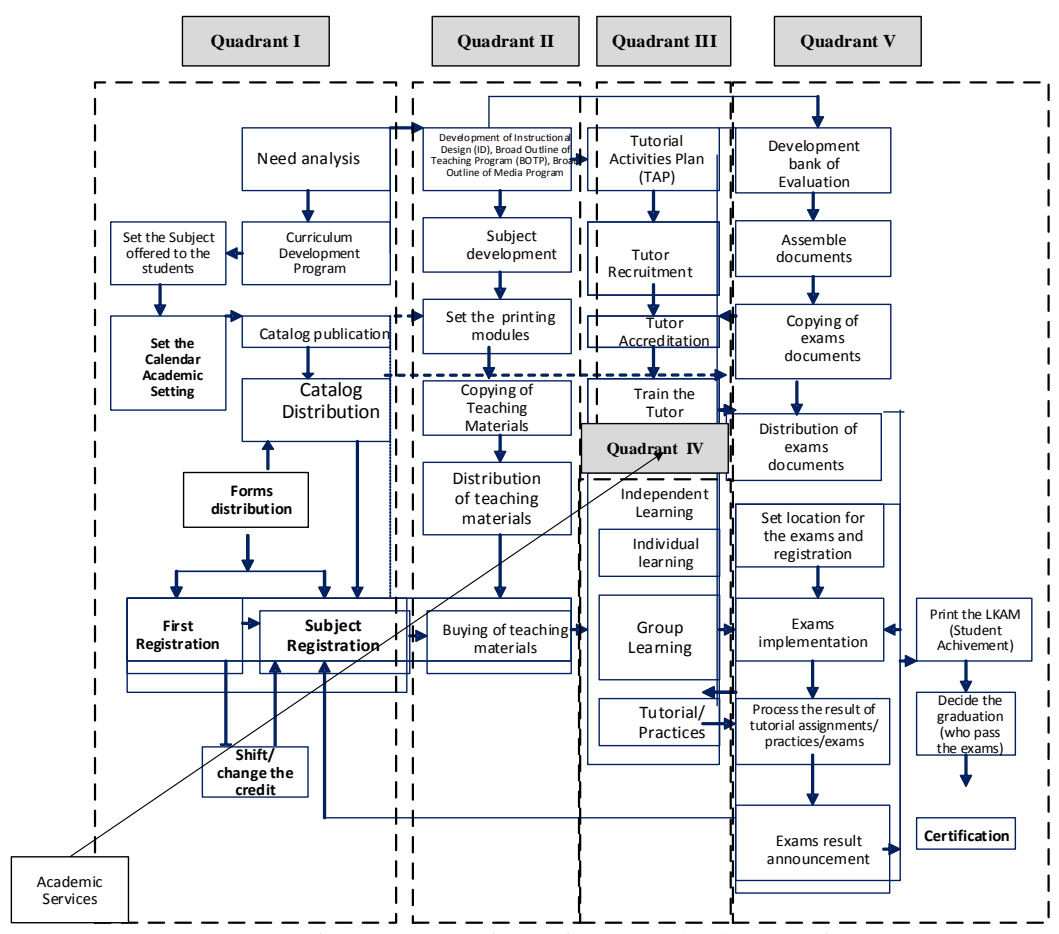

Figure 1 shows the focus of academic activities carried out in quadrant IV. Academic activities are focused on the occurrence of independent learning processes, group learning interactions and tutorial activities. While quadrant $\mathrm{I}$ is a non-academic service. Activities in Quadrant II, are Non Academic Services in the form of support for the academic process. In quadrant III, activities are focused on supporting the teaching and learning process, in the form of providing tutorial services, both face-to-face tutorials and online tutorials. Whereas in quadrant $\mathrm{V}$ it is focused on the process of evaluating learning outcomes.

Figure 1. Universitas Terbuka Business Process 2018-2020

Some studies on student satisfaction with learning services show that there are several aspects of service that are the focus of student attention. While the least important are those associated with the physical facilities. 1) Teaching ability of staff; 2) Subject expertise of staff; 3) IT facilities; 4) lecturer; 5) Supplementary lecture materials. With regard to facilities, students have ranked the importance of IT facilities very highly. International (non-EU) students, mostly Asian from China, India and Pakistan, ranked "textbook availability within the LRC" as the most important aspect of the service. This is indicative of the learning style of many international students. Experience and anecdotal evidence of the Chinese education system, with the textbook teaching structured round and the examination also based on the textbook. Depth of knowledge on one text is expected, rather than bread of knowledge from number of sources[6].

While research at Edge Hill University College showed that student satisfaction with university services that were considered most important was related to: (1) lecture system; (2) price and quality of food; (3) publicity related to students' union; (4) opportunities for training for students; and; and (5) giving feedback in the learning process ([7]. Research in Finland on students and academic staff shows that the most important facilities and providing the highest satisfaction for students is a comfortable learning environment, in the form of public space and campus accessibility. While the staff satisfaction is characterized by a comprehensive campus and complete 
Respondent at UT Regional Office

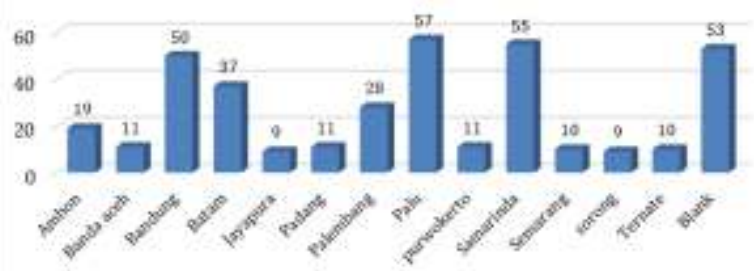

laboratories and teaching facilities. In general, the results show that the factors related to the field of research and teaching have the greatest impact on student satisfaction and staff[8].

\section{Research Methods 4.1 Research Samples}

This study was conducted with a survey method using a questionnaire.The research sample was UT students from 13 UT Regional Offices in Indonesia, with the number of samples per UT Regional Office as in Figure 2.Samples were taken by purpose sampling method by considering the representation of the regions of Western Indonesia, Central Indonesia and Eastern Indonesia. The number ofsamples for each UT Regional Office is shown in Figure 2

\subsection{Processing and analysis of data}

Analysis of student satisfaction with Universitas Terbuka academic services quantitatively using Importance-Performance Analysis (IPA)[9] and Customer Satisfaction Index (CSI)[10] analysis Figure 2 Respondent at UT Regional Office

tools. IPA is used to determine the gap between performance and expectations of service products and the CSI which is used to analyze the overall level of customer satisfaction [11].

The results of the analysis with IPA and CSI are explained in Figure 3 and Table 1 below.

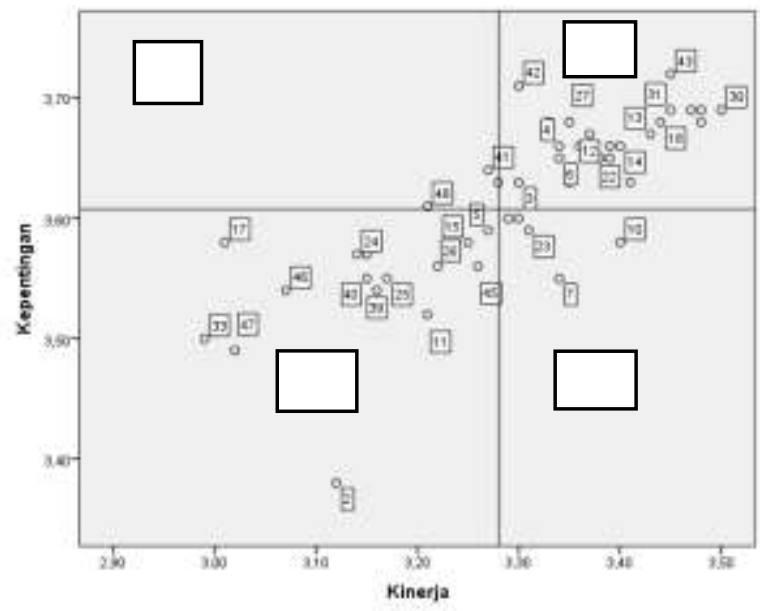

Figure 3. Index Performance Analysis
Quadrant A:In this position, PTJ attributes are considered important by the respondents, but the level of satisfaction obtained is still very low. So that students demand an improvement in these attributes. UT as a PTJJ institution should make an effort to improve the performance of attributes in quadrant A so that student satisfaction can be achieved.

Quadrant $B:$ In this position, attributes that are considered important by students and so that the level of satisfaction is relatively high. This means demanding UT to maintain its position, because these attributes have attracted students to utilize the educational services provided by UT.

Quadrant C:In this position, attributes that are considered less important by respondents and in reality students feel low performance. Increasing the attributes in this quadrant can be reconsidered because the effect on the benefits felt by students is very small.

Quadrant D:In this position, contains attributes that are considered less important by respondents and are felt to be too excessive. Therefore, the attributes included in this awareness can be reduced so that UT can save costs and resources.

Table 1. CSI PTJJ Attributes

\begin{tabular}{|c|c|c|c|c|c|}
\hline \multirow[t]{2}{*}{ NO } & Indicators & $\begin{array}{l}\text { Perfor- } \\
\text { mance }\end{array}$ & Interest & $\begin{array}{c}\text { CSI } \\
\mathrm{E} / 5 \\
\end{array}$ & Quadrant \\
\hline & $\mathbf{A}$ & B & $\mathbf{C}$ & $\mathbf{F}$ & $\mathbf{G}$ \\
\hline & Distance learning courses and education models & & & & \\
\hline 1 & Accreditation of study programs you choose at UT & 3.29 & 3.60 & $90.47 \%$ & $\mathrm{D}$ \\
\hline 2 & The amount of tuition fees that you pay each semester & 3.12 & 3.38 & $85.72 \%$ & $\mathrm{C}$ \\
\hline 3 & Your timeliness in completing the study & 3.30 & 3.63 & $90.77 \%$ & $\mathrm{~B}$ \\
\hline 4 & The GPA value for each semester is & 3.34 & 3.66 & $91.74 \%$ & $\mathrm{~B}$ \\
\hline 5 & Certification acquisition ISO in guaranteeing UT service quality & 3.27 & 3.59 & $89.88 \%$ & A \\
\hline
\end{tabular}




\begin{tabular}{|c|c|c|c|c|c|}
\hline \multirow{2}{*}{ NO } & Indicators & $\begin{array}{l}\text { Perfor- } \\
\text { mance }\end{array}$ & Interest & $\begin{array}{c}\text { CSI } \\
\text { E / } 5\end{array}$ & Quadrant \\
\hline & A & B & $\mathbf{C}$ & $\mathbf{F}$ & $\mathbf{G}$ \\
\hline 6 & $\begin{array}{l}\text { Compliance with existing study programs at the Universitas Terbuka } \\
\text { with needs at work }\end{array}$ & 3.34 & 3.65 & $91,81 \%$ & $\mathrm{~B}$ \\
\hline 7 & $\begin{array}{l}\text { Flexible learning model in the Universitas Terbuka with the } \\
\text { availability of your time }\end{array}$ & 3.34 & 3.55 & $91.74 \%$ & $\mathrm{D}$ \\
\hline 8 & The benefits of the learning material you get at UT in your knowledge & 3.48 & 3.69 & $95.68 \%$ & $\mathrm{~B}$ \\
\hline 9 & $\begin{array}{l}\text { Benefits of the learning material that you process at UT in helping } \\
\text { assignments at work }\end{array}$ & 3.35 & 3.63 & $92.03 \%$ & B \\
\hline 10 & Learning Models at UT in forming independent attitudes & 3,40 & 3.58 & $93.45 \%$ & $\mathrm{D}$ \\
\hline \multirow[t]{2}{*}{11} & $\begin{array}{l}\text { Application technology in defense the range in TU can be easily } \\
\text { utilized }\end{array}$ & 3.21 & 3.52 & $88.24 \%$ & $\mathrm{C}$ \\
\hline & Registration & & & & \\
\hline 12 & Announcement of registration schedule for each semester & 3.37 & 3.67 & $92.63 \%$ & $\mathrm{~B}$ \\
\hline 13 & Ease in registering & 3.43 & 3.67 & $94.34 \%$ & B \\
\hline 14 & Registration process at UPBJJ and Pokjar & 3.40 & 3.66 & $93.45 \%$ & B \\
\hline 15 & The length of time required in the registration process & 3.25 & 3.58 & $89.43 \%$ & $\mathrm{C}$ \\
\hline 16 & $\begin{array}{l}\text { Hospitality and assistance provided when carrying out the service } \\
\text { process registration }\end{array}$ & 3.39 & 3.65 & $93.30 \%$ & B \\
\hline \multirow[t]{2}{*}{17} & $\begin{array}{l}\text { Have you ever done an online registration system? If "yes" How is the } \\
\text { quality of the implementation of the online registration system }\end{array}$ & 3.01 & 3.58 & $82.74 \%$ & $\mathrm{C}$ \\
\hline & Teaching Materials (modules and non-print teaching materials) & & & & \\
\hline 18 & $\begin{array}{l}\text { Course module teaching materials that you take each semester are } \\
\text { always available }\end{array}$ & 3.44 & 3.68 & $94.49 \%$ & B \\
\hline 19 & Modules are always received on time every semester & 3.30 & 3.60 & $90,85 \%$ & $\mathrm{D}$ \\
\hline 20 & Module size (A5) and the type of letters used can be read well & 3.41 & 3.63 & $93.74 \%$ & $\mathrm{~B}$ \\
\hline 21 & $\begin{array}{l}\text { condition of the module you received ( } 4 \text { torn / disabled / there are } 4 \\
\text { parts read) }\end{array}$ & 3.47 & 3.69 & $95.45 \%$ & $\mathrm{~B}$ \\
\hline 22 & The material presented in the Module is well understood & 3.39 & 3.66 & $93.22 \%$ & $\mathrm{~B}$ \\
\hline 23 & $\begin{array}{l}\text { Illustration (in the form picture) can help you understand module } \\
\text { material }\end{array}$ & 3.31 & 3.59 & $91.07 \%$ & $\mathrm{D}$ \\
\hline 24 & Quality presentation of non-printteaching materials Audio & 3.14 & 3.57 & $86.46 \%$ & $\mathrm{C}$ \\
\hline 25 & Quality of presentation of non-printteaching materials video & 3.17 & 3.55 & $87.20 \%$ & $\mathrm{C}$ \\
\hline \multirow[t]{2}{*}{26} & $\begin{array}{l}\text { Material presented in Audio and Video teaching materials help your } \\
\text { understanding. }\end{array}$ & 3.22 & 3.56 & $88.69 \%$ & $\mathrm{C}$ \\
\hline & Face-to-face tutorials and online tutorials & & & & \\
\hline 27 & Location of easy-to-reach face-to-face tutorial services & 3.35 & 3.68 & $92.03 \%$ & B \\
\hline 28 & Face-to-face tutorial services help you understand module material & 3.48 & 3.68 & $95.60 \%$ & B \\
\hline 29 & Mastery of material by tutor tutor & 3.38 & 3.65 & $92.85 \%$ & B \\
\hline 30 & Number of face-to-face Tutorial meetings 8 times in one semester & 3.50 & 3.69 & $96.27 \%$ & $\bar{B}$ \\
\hline 31 & face-to-face tutorial materials help you in understanding modules & 3.45 & 3.69 & $94.86 \%$ & $\mathrm{~B}$ \\
\hline 32 & Timing for conducting face-to-face tutorial services on time & 3.33 & 3.68 & $91.59 \%$ & $\mathrm{~B}$ \\
\hline 33 & Online tutorials are easily accessible & 2.99 & 3.50 & $82.37 \%$ & $\mathrm{C}$ \\
\hline 34 & $\begin{array}{l}\text { Material in online tutorials helps you in understanding module } \\
\text { material }\end{array}$ & 3.01 & 3.51 & $82.74 \%$ & B \\
\hline 35 & There are facilities to access online tutorial services & 3.01 & 3.51 & $82.67 \%$ & B \\
\hline \multirow[t]{2}{*}{36} & Convenience contacting staff UT Puat / UPBJJ-UT / Manager / Tutor & 3.28 & 3.63 & $90.18 \%$ & $\mathrm{~B}$ \\
\hline & Learning assistance counseling services & & & & \\
\hline 37 & Counseling / guidance services are available at UPBJJ & 3.15 & 3.57 & $86.61 \%$ & $\mathrm{C}$ \\
\hline 38 & Independent exercises can be accessed easily online & 3.13 & 3.54 & $86.09 \%$ & $\mathrm{C}$ \\
\hline 39 & $\begin{array}{l}\text { Digital library services can be accessed throughcommunication } \\
\text { devices mobile(handpone) }\end{array}$ & 3.16 & 3.54 & $86.91 \%$ & $\mathrm{C}$ \\
\hline 40 & $\begin{array}{l}\text { Academic services (such as online tutorials, online registration, online } \\
\text { bookstores) can be accessed via a mobile phone }\end{array}$ & 3.15 & 3.55 & $86.53 \%$ & $\mathrm{~B}$ \\
\hline 41 & $\begin{array}{l}\text { The quality of UT's academic services and student complaint services } \\
\text { makes it easy for you to study at UT }\end{array}$ & 3.27 & 3.64 & $89.95 \%$ & $\mathrm{~A}$ \\
\hline \multirow[t]{2}{*}{42} & $\begin{array}{l}\text { The quality of academic services UT can help you in solving problems } \\
\text { that you encounter while studying at UT }\end{array}$ & 3.30 & 3.71 & $90.70 \%$ & $\mathrm{~B}$ \\
\hline & Learning evaluation & & & & \\
\hline 43 & $\begin{array}{l}\text { You are always reminded about the schedule of theSemester Final } \\
\text { Examination }\end{array}$ & 3.45 & 3.72 & $94.86 \%$ & B \\
\hline 44 & The location of the easy semester final exam is & 3.36 & 3.66 & $92.48 \%$ & $\mathrm{~B}$ \\
\hline 45 & Facilities available at the test location are very adequate & 3.26 & 3.56 & $89.73 \%$ & $\mathrm{C}$ \\
\hline 46 & You can access the Online Exam (SUO) & 3.07 & 3.54 & $84.38 \%$ & $\mathrm{C}$ \\
\hline 47 & The Online Examination System can be done easily & 3.02 & 3.49 & $83.19 \%$ & $\mathrm{C}$ \\
\hline 48 & $\begin{array}{l}\text { Schedule of achievements announcements every semester is always on } \\
\text { time }\end{array}$ & 3.21 & 3.61 & $88.32 \%$ & $\mathrm{~A}$ \\
\hline
\end{tabular}




\begin{tabular}{|c|c|c|c|c|c|}
\hline \multirow{2}{*}{ NO } & Indicators & Perfor- & Interest & CSI & \multirow{2}{*}{ Quadrant } \\
\cline { 2 - 6 } & mance & E /5 & \\
\hline & A & B & C & F & G \\
\hline & Total & $\mathbf{1 5 7 , 4 0}$ & $\mathbf{1 7 3 , 1 8}$ & & \\
\hline
\end{tabular}

$0-25 \%=$ very less; $26-50 \%=$ less $; 51-75 \%=$ good $; 75-100 \%=$ very good

\section{Discussion and Conclusions}

\subsection{Discussion}

In general, the level of student satisfaction with attributes PTJJ attribute is at the value of $90.20 \%$. That is, students feel very good satisfaction with the services provided by UT include aspects of distance education study programs and models, registration, teaching materials (modules and nonprint teaching materials), face-to-face tutorials and online tutorials, learning assistance counseling services, and evaluation learn.

When examined in more detail, there are several aspects that are above or below the index value (90.20\%), for example the number of face-to-face Tutorial meetings 8 times in one semester and online Tutorials can be accessed easily.

Data analysis using Importance Performance Analysis shows that 54\% (26 types of services) UT service performance has been in Quadrant B, which means that most of the academic services provided are in accordance with student expectations. Academic services that are already in Quadrant B are registration services and tutorial services. Meanwhile 3 services $(6.3 \%)$ are in QuadrantA, which means this service is considered very important for students, but performance is still low. The servicesare(1) Certification ISO in guaranteeing UT service quality; (2) Student complaint services; dan (3) Schedule of achievements announcements every semester. 14 UT academic service items $(29.2 \%)$ are in Quadrant C, which means that the service is not too important for students and has low performance. The service is related to registration; the quality of audio teaching materials and video teaching materials; counseling services and examinations. While services that are considered not important by students and have a high enough performance amounted to 5 services (10.4\%). The service is related to module teaching materials; study program accreditation and learning flexibility at UT.

\subsection{Conclusions}

Based on the results of research and analysis of data on academic service performance in UT using the Customer Satisfaction Index, it was concluded that the quality of UT's academic services to students had very good performance. However, judging from the analysis of Importance Performance Analysis, further evaluation of academic services still needs to be improved and academic services that are considered less important for students.

This analysis can increase the effectiveness and efficiency of UT's services in the future.

\section{Bibliography}

[1] Bates AW. Distance Education Second edition. 2005.

[2] Kim BK, Bonk CJ. The Future of Online Teaching and Learning in Higher Education: The Survey Says ... A survey substantiates some ideas about online learning and refutes others. High Educ Q [Internet]. 2006;29(4):22-30. Available from: http://www.educause.edu/EDUCAUSE+Quarterly/EDUCAUSEQuarterlyMagazineVolum/The FutureofOnlineTeachingandLe/157426

[3] Rencana Strategis Bisnis UT Tahun 2016-2020. 2018.

[4] Paul Szwarc. Researching Customer Satisfaction \& Loyalty how to Find Out what People Really think. London \& Sterling, VA: Kogan Page; 2005.

[5] Nigel Hill, Self Bill RG. Customer Satisfaction Measurement for ISO 9000:2000. Linacre House, Jordan Hill, Oxford: Butterworth-Heinemann; 2002.

[6] Alstete, Jeffrey W, Buell N. Quality Assurance in Education Article information: Qual Assur 
Educ. 2016;14(3):251-67.

[7] Aldridge, S. \& Rowely J. Measuring Customer Satisfaction in Higher Education, Quality Assurance in Education. 1998;6(4)(4):197-204.

[8] Sami Karna; Päivi Julin. A framework for measuring student and staff satisfaction with university campus facilities. Qual Assur Educ Vol 23 No 1, 2015 pp 47-66 ( E) Emerald Gr Publ Ltd 0968-4883 DOI 101108/QAE-10-2013-004. 2015; Vpl 23.(No.1):47-66.

[9] Lewis R. Importance-performance analysis. Australas J Eng Educ. 2004;2:1-8.

[10] Fandy Tjiptono and Gregorius Chandra. Service, Quality \& Satisfaction. Yogyakarta: Andi; 2011. 319 p.

[11] Handi Irawan. 10 Prinsip Kepuasan Pelanggan. Jakarta: PT Elex Media Komputindo; 2004. 45 p. 